\title{
THE NATIONAL NO MAN'S LAND. IMAGINING RURALITY IN THE ROMANIAN LITERARY HISTORIES
}

In the Manifesto of the Communist Party, in the only fragment problematizing the rural world, Karl Marx and Friedrich Engels express an idea leading to endless controversies mainly among the successive generations of Marxists:

The bourgeoisie has subjected the country to the rule of the towns. It has created enormous cities, has greatly increased the urban population as compared with the rural, and has thus rescued a considerable part of the population from the idiocy of rural life. Just as it has made the country dependent on the towns, so it has made barbarian and semi-barbarian countries dependent on the civilized ones, nations of peasants on nations of bourgeois, the East on the West ${ }^{1}$.

Of course, the polemics relate mostly to phrases such as "the idiocy of rural life" or the synonymy set between the "barbarian and semi-barbarian countries" and the "nations of peasants". The term "idiotismus" in the original text in German, translated in the English versions by "idiocy", and in the French ones by "l'abrutissement", gathers the most heated debates; for example, Eric S. Hobsbawm maintains that "idiotismus" does not refer to intellectual or spiritual primitivism, but to the isolation from society (since the Greek term "idiotes" means the person concerned only with his own private affairs and not those of the wider community $)^{3}$. Regardless of the more or less cynical significance attached to them, and even beyond their truth value (because the interposition of the bourgeois/capitalistic relations in the country generates an erosion of the rural at least as unsettling as the one of the feudal order $^{4}$ ), the sentences by Marx and

\footnotetext{
${ }^{1}$ Karl Marx, Friedrich Engels, Manifesto of the Communist Party, Peking, Foreign Languages Press, 1970 (Reproduction of the translation made by Samuel Moore in 1888), p. 36.

${ }^{2}$ Karl Marx, Friedrich Engels, Le manifeste du parti communiste. Édité par Malaeska Classique, 2017 (Traduction par Laura Lafargue, realisée en 1895).

${ }^{3}$ For a substantial presentation of the topic, see Anne Fay Hirsch Moffitt, Reviving the Rural: The Modernist Poetics of the 20th Century Rural Novel. A dissertation presented to the faculty of Princeton University in candidacy for the degree of doctor of philosophy, April 2012 (https://dataspace.princeton.edu/jspui/handle/88435/dsp01s4655g61g - Accessed April 25, 2018).

${ }^{4}$ See Raymond Williams, The Country and the City, New York, Oxford University Press, 1973, pp. 302-303. A confirmation of this idea is offered also by C. Dobrogeanu-Gherea, in Neoiobăgia. Studiu economico-sociologic al problemei noastre agrare [Neo-serfdom. Economic-sociological Study of Our Agrarian Problem] (Bucharest, Editura Librăriei Socec \& Comp., 1910). Despite the Romanian Marxist ideologue's statements of intent regarding the "profound discord" between "our civilized institutions and the mostly Oriental and half-feudal reality of life" (p. 9), "neo-serfdom" is not so much the outcome of the application of the capitalist relations in the country ("peasants sought and claimed the abolition of serfdom and not the introduction of the liberal-bourgeois institutions; they would have been satisfied sooner with the absolute monarchy of a Voivode who would have freed
} 
Engels point to a major shift of perspective on rurality, developed midway through the $19^{\text {th }}$ century in the West, respectively at the beginning of the $20^{\text {th }}$ in East Europe and South and North America. Against the backdrop of the extension of socialist movements, the peasants started to be seen as a distinct social class, i.e., borrowing a critical metaphor of Raymond Williams in The Country and the City, the rural space detached from its condition of mere landscape (which would literally translate as "land" + „shape" - "the shape of land”) and it acquired an increasingly more prominent identity-related substance. In other words, while in Jane Austen's novels - observes Raymond Williams - rurality was represented by an absent community, because the novelistic spaces were occupied exclusively by the landowners' manors (the remaining territory was mentioned solely for weatherrelated insights or as a promenade) starting with George Eliot and especially with Thomas Hardy, the villages were populated with faces and voices whose individualization and social and psychological outlines grew better and better ${ }^{5}$. Although she starts from completely different premises (identity between the people and nation under the influence of Herderianism), Pascale Casanova identified a similar mutation at the end of the $19^{\text {th }}$ century - the transition from the nation-people to the class-people:

Hence the ambiguity: from now on the "people" was not only another name for a national community taken as a whole, whose classic incarnation was the mythical peasantry, a sort of quintessence of the nation; it also designated - and these notions were in no way contradictory, but rather cumulative - a part of this national whole, consisting of the so-called classes populaires, or working classes 6 .

And even in the only two Romanian studies about the evolution of homegrown rural literature, by the use of wide temporal cut-outs (Sultana Craia, Universul rustic în literatura română [The Rustic Space in the Romanian Literature], respectively Nicolae Bârna, Ipostaze ale modernizării prozei rurale [Aspects of Rural Prose Modernization]), I may extricate the same awareness of the dissociation between the two approaches of rurality: the decorative-naturalistic approach and the social-problematizing one. The former, by promoting almost exclusively a visual screening of existence, would create the "rustic", mainly lyrical literature, while the latter - by targeting a grasp on "the sphere of the social and, later, political behavior, mindset, structure and tensions" ${ }^{\text {"7 }}$ - could be the basis

them" - p. 29, respectively "not at all able to sit on the new stand on which it was placed, our country opted for the old, feudal-serfdom one" - p. 60) as it is the very "natural" effect of the said brutal insertion.

${ }^{5}$ Passim Raymond Williams, The Country, pp. 167-208.

${ }^{6}$ Pascale Casanova, The World Republic of Letters. Translated by M. B. DeBevoise, Cambridge, Harvard University Press, 2004, p. 224.

${ }^{7}$ Sultana Craia, Universul rustic în literatura română [The Rustic Space in the Romanian Literature], Bucharest, Eminescu, 1985, p. 6. 
of "rural" literature itself, an epic and analytical literature of the individual or collective "voices" rather than of "the sight".

Therefore, despite the major differences and even the significant development lags among the previously mentioned literary systems (Williams refers to the English one, Casanova focuses on the dominated, peripheral ones - Irish, South American, African), we may find that rural literature is a creation of the modern age, that the cliché-free envisioning of rurality sets ups a profound re-semanticizing action for the classicized ideas on national history and identity. Once again by paraphrasing Casanova, especially since many of the case studies in The World Republic of Letters reflect quite faithfully also the case of the Romanian literature, the metamorphoses of the perception of rurality operate like indicator paper for the understanding of the artistic and social mutations of the $19^{\text {th }}$ and $20^{\text {th }}$ centuries: for example, while the 1890-1930 "invention" of Ireland engaged a mystical (neo)Romanticism that spread the idealization and aestheticization of the peasantry that had been proclaimed the essence and the keeper of the "national soul", Ireland's "modernization" is rooted in the establishment of a realism that was "at first a peasant realism", then an urban one ${ }^{9}$. Instead of remaining a spatially and temporally fixed point of reference in relation to the "transient, fugitive and contingent" city, the country emphasizes more noticeably the tensions stemming from the social, ideological, cultural shifts, i.e. precisely the aspects offering historicity to the community and national identities, as well as to the literary forms representing them. From Algeria to Ireland, to England, to Canada, to the United States of America, and to Egypt ${ }^{10}$, this situation is completely verified.

Romania alone seems to be an exception, when we read the Romanian literary histories of the first half of the $20^{\text {th }}$ century and we follow the influential bearing of the rurality they had established.

Although they appear at least two decades later than the series of peasant revolts culminating with the one of 1907 - and, moreover, in the years when the agrarian reforms would be replaced with each new government, the "peasant matter" becoming the core not only of the marginal socialists' political program, but also of a larger number of parties in office, and when rural literature would know a never-before-seen variation of the literary forms/formulae - the histories drawn up by E. Lovinescu (Istoria literaturii române contemporane [History of Contemporary Romanian Literature] - 1926-1929), N. Iorga (Istoria literaturii

\footnotetext{
${ }^{8}$ Nicolae Bârna, Ipostaze ale modernizării prozei rurale. Pavel Dan, Marin Preda, Sorin Titel [Aspects of Rural Prose Modernization. Pavel Dan, Marin Preda, Sorin Titel], Bucharest, Ideea Europeană, 2009, p. 10.

${ }^{9}$ Pascale Casanova, The World, p. 225.

${ }^{10}$ See Anne Fay Hirsch Moffitt, Reviving; Glen Cavallero, The Rural Tradition in the English Novel 1900-1939, London and Basingstoke, The Macmillan Press Ltd, 1977; Florian Freitag, The Farm Novel in North America: Genre and Nation in the United States, English Canada, and French Canada, 1845-1945, Rochester, Camden House, 2013; Samah Selim, The Novel and the Rural Imaginary in Egypt. 1880-1985, New York-London, Routledge, 2004.
} 
românești contemporane [History of Contemporary Romanian Literature] - 1934) and G. Călinescu (Istoria literaturii române de la origini până în prezent [History of the Romanian Literature from the Beginning to the Present Day] - 1941) approached rurality from a perspective strongly bound by the ideas of the beginning of the $19^{\text {th }}$ century. They all share a generalizing and a-temporal view, stiffening up to their suppression the rural space and time. In the three literary histories, the differences relate to the phenomenalization rather than to the substance of rurality.

Contrary to the historiographic principles with which he opens his History... "Since it paints relative rather than absolute values, a people's literature should not be studied in the fixity of a Platonic idea, but in its mobility"11 -, Lovinescu enforces a very restrictive viewpoint on rurality, as well as a sterile and repetitive analytical language.

The critical and sometimes satirical glosses about "Sămănătorism"12 extend to the whole literature with a rural or popular base both before and after the movement led by Nicolae Iorga. In fact, despite some punctual dissociations, the so-called "Sămănătorist" literature is synonym, in Lovinescu's opinion, with what he describes as the agrarian "Poporanism"13 developed at the end of the $19^{\text {th }}$ century, respectively the "peasant" traditionalism after World War I. Subsequently, a phenomenon relatively limited from a temporal viewpoint, with a sociologicalideological platform considerably more prominent than the cultural-literary one ${ }^{14}$, sees the postulation of forecasts and extension, and even spatial expansions so significant that they create the impression of a full monopoly of the domestic literary field/system: the "peasant mysticism" defined by the "exaltation of the rural stratum as the sole reality of our people" generating "a literature saturated with national and rural spirit", "with the over-use of folk poetry and, generally, with peasant rhetoric" 15 are Lovinescu's preferred minimalizing formulae when he writes about Constantin Stere, Ilarie Chendi, Simion Mehedinti or Ion Trivale, on whom he pins a narrowness enforced by the "rural origin". Elsewhere, the generalization becomes hyperbolic:

11 E. Lovinescu, Scrieri 4. Istoria literaturii române contemporane [Writings 4. History of Contemporary Romanian Literature]. Edition by Eugen Simion, Bucharest, Minerva, 1973, p. 11.

12 Taking its name from the cultural magazine Sămănătorul (The Sower), "Sămănătorism" was a conservative, Romanticism-inspired ideology, whose nationalist discourse was rooted in the identification of the so-called authentic national spirit with the idealized archetypal village. The main supporter of "Sămănătorism" was Nicolae Iorga, the most prolific and most frequently translated Romanian historian of all times.

${ }^{13}$ In fact, "Poporanism" (from "popor", meaning "people"), which draws on the Russian norodnicism in its sympathy and gratitude towards the peasantry, often promotes an anti-“Sămănătorist” doctrine, refuting the idealized, archetypal peasant/ country.

${ }_{14}$ Passim. Z. Ornea, Sămănătorismul, $3^{\text {rd }}$ edition revised, Bucharest, Editura Fundației Culturale Române, 1998.

${ }^{15}$ Passim E. Lovinescu, Scrieri 4, p. 13, 18, 62. 
While our society has developed in the sense of differentiation and, thus, of evolution, by the creation of an urban stratum and of a national bourgeoisie with traits of ethnical homogeneity, our ideology and, naturally, literature took the reverse approach by negating the obvious, hence the peasant mysticism of all the cultural movement of the last half of century: the peasant has been seen as the only economic, social reality of the Romanian people. [...] therefrom the theory of peasantry as the sole keeper of the virtues of the race or even of any virtues, therefrom the hatred toward the townsfolk who are but a flawed and featureless conglomerate of different races and, subsequently, the hatred toward urban literature ${ }^{16}$.

As to the axiological considerations, the deprecatory connotations of the term "primitive" (with the variations "primitivism", "primitivity") are abundant in Lovinescu's History: the rural would support the "most primitive" artistic expressions and manifestations of the race, the rural prose of Muntenia, although devoid of contemplative traits and attachment to the past (passéisme), is labelled "as primitive" as Moldavian prose, the refinement and intellectualization of Hortensia Papadat-Bengescu's prose opposes the literature that "lives on senses", "purportedly confined in the world of instincts", namely to "the common predisposition for primitivity"; "the scarcity of the amorphous, brutal and vulgar life material" is ascribed to Mihail Sadoveanu also, while Ion Agârbiceanu is reprimanded for the lack of complexity in the epic constructions, his "too true to nature" characters being rudimentary, since "psychology" is possible solely "in some forms of civilization" 17 .

Thus, in Lovinescu's opinion, rurality means mysticism, primitivism, instinctiveness, psychological precarity, monopoly over the national identity and culture, regress in relation to the society's contemporary and natural evolution. Many of Lovinescu's conceptions and preconceptions have been constantly questioned over time, and even invalidated factually by recent studies. I will give two examples: in Modernitatea politică și literară în gândirea lui E. Lovinescu [Political and Literary Modernity at E. Lovinescu], Teodora Dumitru fittingly proves that while "disconnected from the ethical and the ethnical, the art and its study were not disconnected, at E. Lovinescu, from ideology and science"18, literary modernism reflecting, like a loyal "travel companion", the class interests of the liberal bourgeoisie that was undergoing a consolidation or was triumphant in spite of the socioeconomic situation of most of Romania's population in the first decades of the $20^{\text {th }}$ century; in another study, this time a quantitative analysis of the Romanian novel between 1909 and 1939 (including almost similar data also for the

\footnotetext{
${ }^{16}$ Ibidem, pp. 152-153.

17 Passim E. Lovinescu, Scrieri 5. Istoria literaturii române contemporane [Writings 5. History of Contemporary Romanian Literature]. Edition by Eugen Simion, Bucharest, Minerva, 1973, p. 17, 33, $145,152-153,175$.

18 Teodora Dumitru, Modernitatea politică și literară în gândirea lui E. Lovinescu [Political and Literary Modernity at E. Lovinescu], Bucharest, Editura Muzeul Literaturii Române, 2016, p. 132.
} 
period 1909-1926-1929 - when Lovinescu's History was published), Daiana Gârdan finds that the rural novel barely amounts to $8 \%$ of the total large-sized prose writings of the age, while the erotic one has $25 \%$, the social one with urban themes $28 \%$, the historical and sensationalistic one $9 \%{ }^{19}$.

However, pointing out the cases in which Lovinescu reevaluates the rural literature continues to be the purpose of this paper and more important than the undermining of Lovinescu's definition of literary rurality as a "negation" of the evolutive "proof" of the Romanian society, respectively as literary or identityrelated inflation or monopoly. I refer here especially to the sections on Octavian Goga, Gheorghe Brăescu and Liviu Rebreanu. All three of them would confirm that "the rural material is as likely to become aesthetic as any other material" 20 , so that the imprecation of the Romanian literature's rurality would have been based on an exclusively aesthetic criterion. Nevertheless, the rurality cherished by Lovinescu is void of any particular, identity-related or social symbols; it is a barren land governed by spirits who are no longer of the place, but of a transcendent energy:

When literature descended from poetry to observation and naturalism, country mysticism lost some of its grace, but gained combative violence and fanaticism. Infallibly, the procedures changed: the water color and idyllic blue in the background of the whole work by Grigorescu or Coșbuc were changed for the somber colors of Sadoveanu's naturalism (in fact, also a lyrical one). Country life is no longer painted as an idyll, but as a tragedy of "muffled pain"; the peasant is an elementary force gifted with immense compressed virtuality. Even in the vastest epic creation of Romanian literature, Rebreanu's Ion, where the multiple life of the Transylvanian village is painted [with] such elaborate gestures, with heroes who are so different and so real, Ion's central character exceeds, as said before, reality: he is a larger-than-life peasant, a typical expression of what Nietzsche called the "will to power", of the instinct of domination; thus, a symbolic creation ${ }^{21}$.

Goga's situation is similar; although the extremely influential social component of his poetry is recognized, it (the poetry) also stands out owing to the ability to project symbolically the individual and collective destinies ${ }^{22}$. The only one who could truly generate the shift is Brăescu; his social satire could not only be superior to the one canonized by I. L. Caragiale, but, following in the steps of Balzac, Zola and, especially, Maupassant, it would relieve the peasant "of all the attributes of the poetry and of national mysticism"23: "With such poignant and realistic vision, country (peasant) psychology entered the phase of the reaction

\footnotetext{
19 Daiana Gârdan, "Evoluția romanului erotic românesc din prima jumătate a secolului al XX-lea. Între exercițiu și canonizare" ["Evolution of the Romanian Erotic Novel in the First Half of the $20^{\text {th }}$ Century. Between Exercise and Canonization"], Transilvania, 2018, 7, pp. 23-28.

${ }^{20}$ E. Lovinescu, Scrieri 4, p. 416.

${ }^{21}$ E. Lovinescu, Scrieri 5, p. 230.

${ }^{22}$ E. Lovinescu, Scrieri 4, p. 371.

${ }^{23}$ E. Lovinescu, Scrieri 5, p. 230.
} 
required against the idealization falsifying the facts for almost three quarters of century" 24 . As we can see, Lovinescu does not praise a new aspect of rural reality/literature, but the satirical approach of the old one, mystifying by aestheticization, i.e. the only one that History of Contemporary Romanian Literature is in fact able to conceive.

From this point of view, Lovinescu is not at all more imaginative than Iorga. A cynical modernist's "reality" substitutes an exalted romantic's "reality". By the ideological and methodological refute of Iorga, Lovinescu merely consecrates his artificial projections about rurality. Lovinescu's criticism of the mysticism of primitivism, instinct, simplicity is synonymous with Iorga's mystic rurality of freshness, spontaneity, ingenuity.

In the writers' rural origins or in the direct contact with the peasants, where Lovinescu shapes a nearly unavoidable source of primitivism (as pointed out previously), Iorga envisions the foundation of the freshness and ease of the purely Romanian literary perspective or style: Mihai Eminescu's trip to Transylvania gifted him with "the knowledge of the real life of peasants who did not emerge from Alecsandri's Christmas doll house", "authentic peasants meant to stay like that", unlike the humanity of Cernăuți, "where Austria knew to sterilize souls"25; Ion Creangă's creative strength stems from "the strong representation of the country man at the feet of the Neamt, mountain, a representation that went unspoiled and unadulterated by the years of school, of seminar apprenticeship, of church missions"26, while Ioan Slavici, "the aged student interested in philosophical speculations", turns out to be - in all of his most valuable writings "a peasant who did not forget anything, who has, in fact, the whole encyclopedia of life from the circle of this development" ${ }^{27}$. Predictably, and a very known aspect, Liviu Rebreanu is rejected because, in Ion,

Slavici's and Agârbiceanu's reasonable, respectively highly moral Transylvania is ripped open to see the alleged misery at its heart, with all the fatalities of its decline. It's like the stench emanating from Zola's La Terre, the story of the same elementary passions, therein described with another art, but with the same moral indifference ${ }^{28}$.

Although the rurality conceived by Lovinescu could be made plastic, even with caricatural touches, by thoughtless peasants in the door of a pub, by "the likes of old man Gheorghe and master Andrieș, pulling at a pipe on the veranda of boyars'

\footnotetext{
${ }^{24}$ Ibidem, p. 233.

${ }^{25}$ N. Iorga, Istoria literaturii românești contemporane, I: Crearea formei (1867-1890) [History of Contemporary Romanian Literature, I: Creation of the Form (1867-1890)]. Edition coordinated, notes and index by Rodica Rotaru. Preface by Ion Rotaru, Bucharest, Minerva, 1985, p. 143.

${ }^{26}$ Ibidem, p. 239.

${ }^{27}$ Ibidem, p. 242.

28 N. Iorga, Istoria literaturii românești, II: În căutarea fondului (1890-1934) [The History of Romanian Literature, II: In Search of the Substance]. Edition coordinated, notes and index by Rodica Rotaru. Preface by Ion Rotaru, Bucharest, Minerva, 1986, p. 346.
} 
houses" or by "the likes of Ms. Elencu, who spend their time in the coops of the yard" 29 , Iorga's rurality does not even tolerate a face, but - as put by Zigu Ornea solely the outlines of "the archetypal village, gifted with a primary soul, its authenticity and originality preserved owing to its isolation, as imagined by the sociologists and philosophers who advocated the antinomic understanding between culture and civilization" 30 .

In his 1941 History, G. Călinescu turns out to be even more original (meaning an excessively creative and expressive imagination). This is proven by two excellent studies which at least leave room for punctual emphases, while they do not exhaust the topic of rurality: Mircea Martin, G. Călinescu și „complexele” literaturii române [G. Călinescu and the "Complexes" of the Romanian Literature], respectively Andrei Terian, G. Călinescu. A cincea esență [G. Călinescu. The Fifth Essence]. By dismissing the dichotomies between culture and civilization, between country and city, between the minor culture and the major one, Călinescu challenges both the "primitivism" and the "romanticizing" of the rural, turning his Istoria in a "testimony for" rurality, "a defense" of the same, "a demonstration" of its creative powers, "the rehabilitation of peasant spirituality" occurring not "for freshness, spontaneity, ingenuity, but for 'complexity' and "erudition" "31. The creative interest is not captured by the idyllic "soundness" or by the picturesque "ease, naturalness" or the archaizing "freshness" of the Romanian peasant; instead, it is caught by "nobility" 32 .

The conversion of rurality to nobility, also a "junction point" "for Călinescu's ethnocentric project" and for the avatars of his critical, theoretical, historiographic system, as shown in detail by Andrei Terian ${ }^{33}$, generates an interpretive fiction which is equally fascinating, from a rhetorical-stylistic point of view, and identity destructive for the rural and even national spirituality. At George Coşbuc, whose "specific trait" is retrieved in the "poems with peasant subjects", "the unfolding of the sentiment is ritual, as in barbarian dances, now like a litany, now symmetrically"34; Octavian Goga "was, undoubtedly, a peasant, but a peasant of so ancient and unmingled race that he had aristocrat's traits" 35 , therefore his poetry returns the image of a "transcendentalized" Transylvania, because

\footnotetext{
${ }^{29}$ E. Lovinescu, Scrieri 5, p. 107.

${ }^{30}$ Z. Ornea, Sămănătorismul, p. 217.

31 Mircea Martin, G. Călinescu și „complexele” literaturii române [G. Călinescu and the "Complexes" of the Romanian Literature], $2^{\text {nd }}$ edition, with the author's Argument. Postface by Nicolae Manolescu, Pitești, Paralela 45, 2002, p. 94.

${ }^{32}$ Ibidem, p. 113.

${ }_{33}$ Andrei Terian, G. Călinescu. A cincea esență [G. Călinescu. The Fifth Essence], Bucharest, Cartea Românească, 2009, p. 142.

${ }^{34}$ G. Călinescu, History of Romanian Literature. Translated by Leon Levițchi, Milan, UNESCONagard Publishers, 1988, p. 501.

35 Ibidem, p. 518.
} 
the country described in his poetry has an obvious hermetical character. It is a Purgatory where processional events happen, where the people lament mysteriously, driven by a secret power, with the presentiment of a universal catastrophe. Why do only butterflies grow here and the fields of useless silk? Why does the entire people sing chorally? Why do the waters speak? Why does everybody wail as in an apocalypse? Why this moving ceremonial? The poem's movement is Dantesque and the woe has remained pure, detached from the political content ${ }^{36}$.

No wonder, then, that even Rebreanu's world becomes de-territorialized, socially and politically aseptic; Terian demonstrates that the typicality of his characters is removed from any Balzacianism, bestowed with "universal and noncontingent" ${ }^{\prime 37}$ meanings, since, by applying Călinescu's reading grid,

Ion is not even a novel [...] Ion is the epic work of a poet who describes solemnly the general conditions of life, birth, wedding, death. The novel is made up of cantos, obviously cadenced in the style of the great epopees [...] Ion is an epic poem, solemn like an American river, a masterpiece of quiet magnificence ${ }^{38}$.

And the examples could go on virtually forever, because rurality demonstrates par excellence precisely "the fifth essence" - the ineffable, the indemonstrable, the unanalyzable - by which Andrei Terian defines the core of Călinescu's critical system. Not by chance, Călinescu "transylvanizes" and "ruralizes"39, and thus "specifies", for "universalization", all the great Romanian writers. An additional proof is the "ethnical character" valued in Mihail Sadoveanu's writings, configured also in a universalist terminology: "archive of an unreal primitive people", "Sadoveanu has not created men, he has created a people of absolute barbarity, placed in a sublime and rough setting, majestically legendary, endowed with GetoScythian institutions formulated with the help of imagination" 40 .

This is how, downgraded to a primitive condition by Lovinescu, naturalized through the evacuation of all the temporal, ideological and social contingencies by Iorga, upgraded through universalization by Călinescu, the rurality reflected by the Romanian literature avoids any formal, historical, aesthetic or even identity-related assessments. If a reader unacquainted with the homegrown cultural horizon approached the literary histories drawn up by Lovinescu, Iorga and Călinescu, he/she would find in the Romanian village only preconceptions and mystifications belittling, respectively idealizing the peasant of any time any place. For this reason, the national or downright nationalistic character reproached to Iorga's and Călinescu's histories by the use of the new transnational critical methodologies cannot find a valid argument in the envisioning of rurality. From this point of view,

${ }^{36}$ Ibidem, p. 520.

${ }^{37}$ Andrei Terian, G. Călinescu, p. 176.

${ }^{38}$ G. Călinescu, History, p. 621.

${ }^{39}$ Andrei Terian, G. Călinescu, p. 330.

${ }^{40}$ G. Călinescu, History, p. 541. 
Iorga and Călinescu are as "un-national" as Lovinescu. Not only does their country lack a population of "true" Romanians; it also misses a proper social community. Their rural motherland is safeguarded only by infinite symbols, myths and phantasms.

\section{BIBLIOGRAPHY}

BÂRNA, Nicolae, Ipostaze ale modernizării prozei rurale. Pavel Dan, Marin Preda, Sorin Titel [Aspects of Rural Prose Modernization. Pavel Dan, Marin Preda, Sorin Titel], Bucharest, Ideea Europeană, 2009.

CĂLINESCU, G., History of Romanian Literature. Translated by Leon Levițchi, Milan, UNESCONagard Publishers, 1988.

CASANOVA, Pascale, The World Republic of Letters. Translated by M. B. DeBevoise, Cambridge, Harvard University Press, 2004.

CAVALLERO, Glen, The Rural Tradition in the English Novel 1900-1939, London and Basingstoke, The Macmillan Press Ltd, 1977.

CRAIA, Sultana, Universul rustic în literatura română [The Rustic Space in the Romanian Literature], Bucharest, Eminescu, 1985.

DOBROGEANU-GHEREA, C., Neoiobăgia. Studiu economico-sociologic al problemei noastre agrare [Neo-serfdom. Economic-sociological Study of Our Agrarian Problem], Bucharest, Editura Librăriei Socec \& Comp., 1910.

DUMITRU, Teodora, Modernitatea politică și literară în gândirea lui E. Lovinescu [Political and Literary Modernity at E. Lovinescu], Bucharest, Editura Muzeul Literaturii Române, 2016.

FREITAG, Florian, The Farm Novel in North America: Genre and Nation in the United States, English Canada, and French Canada, 1845-1945, Rochester, Camden House, 2013.

GÂRDAN, Daiana, "Evoluția romanului erotic românesc din prima jumătate a secolului al XX-lea. Între exercițiu și canonizare" ["Evolution of the Romanian Erotic Novel in the First Half of the $20^{\text {th }}$ Century. Between Exercise and Canonization"], Transilvania, 2018, 7, pp. 23-28.

IORGA, N., Istoria literaturii românești contemporane, I: Crearea formei (1867-1890) [History of Contemporary Romanian Literature, I: Creation of the Form (1867-1890)]. Edition coordinated, notes and index by Rodica Rotaru. Preface by Ion Rotaru, Bucharest, Minerva, 1985.

IORGA, N., Istoria literaturii românești, II: În căutarea fondului (1890-1934) [The History of Romanian Literature, II: In Search of the Substance]. Edition coordinated, notes and index by Rodica Rotaru. Preface by Ion Rotaru, Bucharest, Minerva, 1986.

LOVINESCU, E., Scrieri 4. Istoria literaturii române contemporane [Writings 4. History of Contemporary Romanian Literature]. Edition by Eugen Simion, Bucharest, Minerva, 1973.

LOVINESCU, E., Scrieri 5. Istoria literaturii române contemporane [Writings 5. History of Contemporary Romanian Literature]. Edition by Eugen Simion, Bucharest, Minerva, 1973.

MARTIN, Mircea, G. Călinescu și „complexele” literaturii române [G. Călinescu and the "Complexes" of the Romanian Literature], $2^{\text {nd }}$ edition, with the author's Argument. Postface by Nicolae Manolescu, Pitești, Paralela 45, 2002.

MARX, Karl, ENGELS, Friedrich, Le manifeste du parti communiste, Édité par Malaeska Classique, 2017 (Traduction par Laura Lafargue, realisée en 1895).

MARX, Karl, ENGELS, Friedrich, Manifesto of the Communist Party, Peking, Foreign Languages Press, 1970 (Reproduction of the translation made by Samuel Moore in 1888).

MOFFITT, Anne Fay Hirsch, Reviving the Rural: The Modernist Poetics of the 20th Century Rural Novel. A dissertation presented to the faculty of Princeton University in candidacy for the degree of doctor of 
philosophy, April 2012. https://dataspace.princeton.edu/jspui/handle/88435/dsp01s4655g61g. Accessed April 25, 2018

ORNEA, Z., Sămănătorismul, $3^{\text {rd }}$ edition revised, Bucharest, Editura Fundației Culturale Române, 1998.

SELIM, Samah, The Novel and the Rural Imaginary in Egypt. 1880-1985, New York-London, Routledge, 2004.

TERIAN, Andrei, G. Călinescu. A cincea esență [G. Călinescu. The Fifth Essence], Bucharest, Cartea Românească, 2009.

WILLIAMS, Raymond, The Country and the City, New York, Oxford University Press, 1973.

\section{THE NATIONAL NO MAN'S LAND. IMAGINING RURALITY IN THE ROMANIAN LITERARY HISTORIES \\ (Abstract)}

This paper analyzes the concurrent perspectives of the three Romanian literary histories (E. Lovinescu, History of Contemporary Romanian Literature - 1926-1929, N. Iorga, History of Contemporary Romanian Literature - 1934, G. Călinescu, History of Romanian Literature from Its Origins to the Present - 1941), in which rurality acquires the status of central constitutive factor of the theoretical and analytical system. Despite their programmatically divergent historiographical conceptions, Lovinescu, Iorga and Călinescu share - not at all paradoxically - almost similar (abstract, atemporal, aesthetic) projections of the rural universe. Consequently, the imagined rurality in the three histories of Romanian literature puts into crisis precisely what it should have underlined: their historical and/or national character.

Keywords: rural literature, imagined rurality, national myth, literary history, E. Lovinescu, N. Iorga, G. Călinescu.

\section{ȚARA NIMĂNUI. IMAGINAREA RURALITĂȚII ÎN ISTORIILE LITERARE ROMÂNEȘTI (Rezumat)}

Lucrarea analizează perspectivele concordante din cele trei istorii literare românești (E. Lovinescu, Istoria literaturii române contemporane - 1926-1929, N. Iorga, Istoria literaturii românești contemporane - 1934, G. Călinescu, Istoria literaturii române de la origini până în prezent - 1941) în care ruralitatea dobândește statutul de factor constitutiv central al sistemului teoretic și analitic. În ciuda concepțiilor istoriografice programatic divergente, Lovinescu, Iorga și Călinescu împărtășesc deloc paradoxal - proiecții cvasi-similare ale universului rural: abstractizante, atemporale, estetizante. În consecință, ruralitatea imaginată în cele trei istorii ale literaturii române pune în criză tocmai ceea ce ar fi trebuit să fundamenteze: istoricitatea și/sau caracterul lor național.

Cuvinte-cheie: literatură rurală, ruralitate imaginată, mit național, istorie literară, E. Lovinescu, N. Iorga, G. Călinescu. 